\title{
A szívmütétet követő végleges pacemaker-implantáció kérdésköre
}

\author{
Tóth Roland dr. ${ }^{1}$ - Tahin Tamás dr. ${ }^{2}$ - Riba Ádám dr. ${ }^{2}$. Rashed Aref dr. ${ }^{1}$ \\ ${ }^{1}$ Zala Megyei Szent Rafael Kórház, Szívsebészeti Osztály, Zalaegerszeg \\ ${ }^{2}$ Zala Megyei Szent Rafael Kórház, Kardiológiai Osztály, Zalaegerszeg
}

\begin{abstract}
A szívmútét utáni pacemaker-terápiát igénylő ritmuszavarok kérdésköre jól ismert és tanulmányozott, problematikája komoly kihívások elé állítja a szakmát. Írásunk célja összefoglalni a jelenleg érvényes nemzetközi ajánlásokat és a jelentôs tanulmányok eredményeit, valamint ismertetni kórházunk ez irányú tapasztalatait. Bemutatjuk a lényeges európai és amerikai iránymutatásokat és az eddigi meghatározó tanulmányok fóbb eredményeit. Közreadjuk a Zala Megyei Szent Rafael Kórházban 2014. 01. 01. és 2018. 12. 31. között operált 2735 beteg közül a mútét utáni egy hónapon belül végleges pacemaker-implantáción átesettek adatait, és összevetjük azokat a nemzetközi eredményekkel. A nemzetközi irodalom adatai alapján a korai posztoperatív időszakban a végleges pacemaker-beültetés aránya átlagosan 1,5-5\% körül mozog a szívsebészetben, és ez az arány a későbbiekben tovább nő. Az ingerületvezetési zavarok kialakulásáról részletes információkkal rendelkezünk, számos prediktív tényező került azonosításra, az aktuális guideline-ok mégis csak hozzávetőleges iránymutatást kínálnak a kérdésben. A korai perioperatív időszak (1 hónap) során osztályunkon 15 esetben $(0,55 \%)$ volt szükség végleges pacemaker implantációjára, és a késői utánkövetés során 6 beteg bírt továbbra is pacemakerdependens ritmuszavarral. A perioperatív ritmuszavarok gyakori és komoly következményekkel járó szövődmények a szívsebészetben, nehezítik a betegek gyors felépülését, terhet rónak a betegellátásra, és költségtöbbletet jelentenek. A végleges pacemaker-beültetés aránya a Zala Megyei Szent Rafael Kórházban alacsonynak mondható. A késői utánkövetés alapján a betegeknek így is csak töredéke pacemakerdependens. Az eddig rendelkezésre álló információk és egy hazai, nagy esetszámú, prospektív vizsgálat segítségével szükséges lenne standardizált protokoll kialakítása a témában, mely mérvadó lenne a szakma számára.
\end{abstract}

Orv Hetil. 2020; 161(31): 1271-1280.

Kulcsszavak: szívsebészet, ritmuszavar, pacemaker-beültetés, irányelvek, protokoll

\section{The issue of permanent pacemaker implantation following cardiac surgery}

The issue of postoperative arrhythmias requiring pacemaker therapy is widely studied in the field of cardiac surgery and it is a complex perioperative problem. The aim of this paper is to summarize the relevant international guidelines and recommendations and to present our hospital's experience. We present the current, decisive recommendations and important studies, and present patients who underwent pacemaker implantation within one month after cardiac surgery between 01.01. 2014 and 31.12.2018 in our hospital and compare them with the international findings. According to the international literature, the rate of permanent pacemaker implantation after cardiac surgery ranges from about $1.5 \%$ to $5 \%$, and this rate seems to increase later. We have detailed information and many identified predictors about the development of conduction disturbances, but the current guidelines provide only weak recommendations. In the early perioperative period ( 1 month), pacemaker implantation was required in 15 cases $(0.55 \%)$; in the course of long-term follow-up, 6 patients were still pacemaker-dependent. Perioperative arrhythmias are frequent and serious complications after cardiac surgery, prolong patient recovery time and put financial burden on the hospitals. The rate of need for a permanent pacemaker is low in our hospital, and in the late follow-up we can find only a small part of patients with pacemaker dependency. It would be necessary to start a prospective study and to develop a standardized protocol based on the information currently available. This would be a useful and authoritative help for the postoperative care in cardiac surgery.

Keywords: cardiac surgery, arrhythmias, pacemaker implantation, guidelines, protocol

Tóth R, Tahin T, Riba Á, Rashed A. [The issue of permanent pacemaker implantation following cardiac surgery]. Orv Hetil. 2020; 161(31): 1271-1280.

(Beérkezett: 2020. március 30.; elfogadva: 2020. április 30.) 


\section{Rövidítések}

ACC = American College of Cardiology; AHA = American Heart Association; AMI = (acute myocardial infarction $)$ akut myocardialis infarctus; $\mathrm{AV}=$ atrioventricularis; $\mathrm{AVR}=($ aortic valve replacement) aortabillentyú cseréje; $\mathrm{CABG}=$ (coronary artery bypass grafting) koszorúér-áthidalás; $\mathrm{CK} \mathrm{MB}=$ creatine kinase myocardial band; $\mathrm{CPB}=$ cardiopulmonary bypass; $\mathrm{CRT}=($ cardiac resynchronization therapy $)$ reszinkronizációs terápia; $\mathrm{CX}=$ (circumflex coronary artery) a bal fötörzs körbefutó ága; EKG = elektrokardiográfia $; \mathrm{ESC}=$ European Society of Cardiology; HRS = Heart Rhythm Society; ICD = (implantable cardioverter-defibrillator) implantálható cardioverter defibrillátor; ITO = Intenzív Terápiás Osztály; LAD = (left anterior descending coronary artery) a bal fótörzs leszálló ága; $\mathrm{LBBB}=$ (left bundle branch block) bal-Tawara-szár-blokk; $\mathrm{LM}=($ left main coronary artery) bal fötörzs; MVP $=($ mitral valvuloplasty) mitralis billentyú plasztikája; $M V R=$ (mitral valve replacement) mitralis billentyü cseréje; NYHA = New York Heart Association; $\mathrm{PF}=$ pitvarfibrilláció; $\mathrm{PM}=$ pacemaker; PPM = (permanent pacemaker) állandó pacemaker; SND = (sinus node dysfunction) a sinuscsomó múködési zavara; TVP $=$ (tricuspid valvuloplasty) tricuspidalis billentyú plasztikája; TVR $=$ (tricuspid valve replacement $)$ tricuspidalis billentyư cseréje

A szívsebészeti beavatkozások kapcsán fellépő, állandó pacemaker (PPM) beültetését igénylő ritmuszavarok adatelemzésével már sok nemzetközi tanulmány foglalkozott, hosszú távú utánkövetésük azonban - különösen Magyarországon - ez idáig hiányosnak mondható; tanulmányunkkal ezt a feladatot igyekeztünk pótolni. A nemzetközi irodalom elveinek összegzésén túl egy kisebb esetszámú betegcsoport adatait elemeztük, és próbáltunk tendenciaszerú összefüggéseket találni a PPMbeültetést igénylő ritmuszavarokat illetően, azokat a nemzetközi eredményekkel összevetni és ezek alapján olyan következtetéseket levonni, amelyekkel javítható lehet a betegek kezelése.

A billentyúbetegségekhez és azok műtéti megoldásaihoz kapcsolódó ingerületvezetési zavarok problémaköre régóta ismert. Az aortabillentyü meszesedése és az atrioventricularis (AV-) blokk kialakulása közötti összefüggést 1935-ben Yater és Cornell írta le, 1963-ban pedig Sellers és mtsai állapították meg a mechanikus aortabillentyű beültetése és az utána fellépő ingerületvezetési zavar közötti kapcsolatot $[1,2]$.

A szívmútétek utáni korai posztoperatív időszakban fellépő AV-blokk kialakulásának körülményeit és a lehetséges lefolyást az 1. ábra szemlélteti [3]. Egyes tanulmányok szerint koszorúér-áthidalást (CABG [coronary artery bypass grafting]) követően előfordulása $0,5-16 \%$ közötti, billentyú (aorta, mitralis, tricuspidalis, illetve ezek kombinációja) miatti reoperáció esetén az arány $8 \%$, tricuspidalis billentyú mútéte után $20 \%$ körüli is lehet [4-7]. A posztoperatív bradycardia kialakulásának esélye függ a beavatkozás típusától és annak az ingerületvezető rendszerhez való anatómiai viszonyától [8].
A posztoperatív bradyarrhythmiák kezelésének egyik legfontosabb szempontja a sinus- és az AV-csomó funkciójának megítélése a PPM beültetése előtt [9]. Egyes ritmuszavarok megszúnnek pár nappal a mútét után, míg sok esetben perzisztálnak. Az utóbbi helyzetben általában a PPM-implantáció nem operált betegekre érvényes szabályai lépnek életbe [9]. Nyolc nagy tanulmány metaanalízisének eredményei szerint a 6-72 hónapos utánkövetés során a PPM-es betegek 32-91\%-a volt még mindig dependens, míg az AV-átvezetési zavar 1642\%-ban szúnt meg [3]. Ezzel szemben egy hosszú utánkövetéssel bíró másik kutatás 84 PPM-es betege közül csak 10\% nem volt PM-függő, 79\%-uk állandó kamrai stimulációra szorult, 11\%-uknál pedig időszakos PM-múködést írtak le [10].

A mútét utáni felépülés meggyorsítása érdekében (korai intenzív terápiás osztályos [ITO-] emisszió, a mobilizálás megkezdése, antikoaguláns kezelés felépítése) ajánlott a PPM-implantáció idejének optimalizálása. A PPM beültetése megnövelheti a kórházi tartózkodás időtartamát, a rehospitalizációs arányt, és ezáltal jelentős hatása van az ellátási költségekre, sőt a hosszú távú mortalitást is negatívan befolyásolhatja $[11,12]$.

Az egyik legnagyobb esetszámú, 350000 beteg adatait feldolgozó tanulmány leírta a különféle szívmútétek utáni PPM-implantáció és mortalitás adatainak nagyarányú különbözőségeit, s az eredményeket hosszú távon (14 év) is követték. A PPM-implantáció adatait az 1. táblázat szemlélteti. A 14 éves mortalitási adatok a CABG, AVR (aortic valve replacement), MVR (mitral valve replacement), AVR + MVR, AVR + MVR + TVR (tricuspid valve replacement) mütéteknek megfelelően növekvô tendenciát mutattak: $20,5 \%, 26,8 \%, 30,1 \%, 36,8 \%$, 39,5\%. A PPM-implantáció szempontjából független prediktorként a kort, a férfinemet, a sürgősségileg felvett beteget, illetve a korábban fennálló diabetes mellitust, szívelégtelenséget vagy vesekárosodást határozták meg [13].

1. táblázat A végleges pacemaker beültetésének arányai különböző szívmútéttípusok után Leyva és mtsai [13] adatai alapján

\begin{tabular}{lccc}
\hline Mútéttípus & $\begin{array}{c}\text { Közvetlenül } \\
\text { a mútét után }\end{array}$ & l év múlva & 10 év múlva \\
\hline CABG & $0,67 \%$ & $1,13 \%$ & $5,11 \%$ \\
AVR & $4,22 \%$ & $5,9 \%$ & $14,4 \%$ \\
MVR & $4,38 \%$ & $6,2 \%$ & $15,6 \%$ \\
AVR + MVR & $5,59 \%$ & $8,3 \%$ & $18,3 \%$ \\
AVR + MVR + TVR & $7,89 \%$ & $11,2 \%$ & $25,9 \%$ \\
\hline
\end{tabular}

AVR = aortabillentyú cseréje; CABG = koszorúér-áthidalás; MVR = mitralis billentyú cseréje; TVR = tricuspidalis billentyú cseréje 

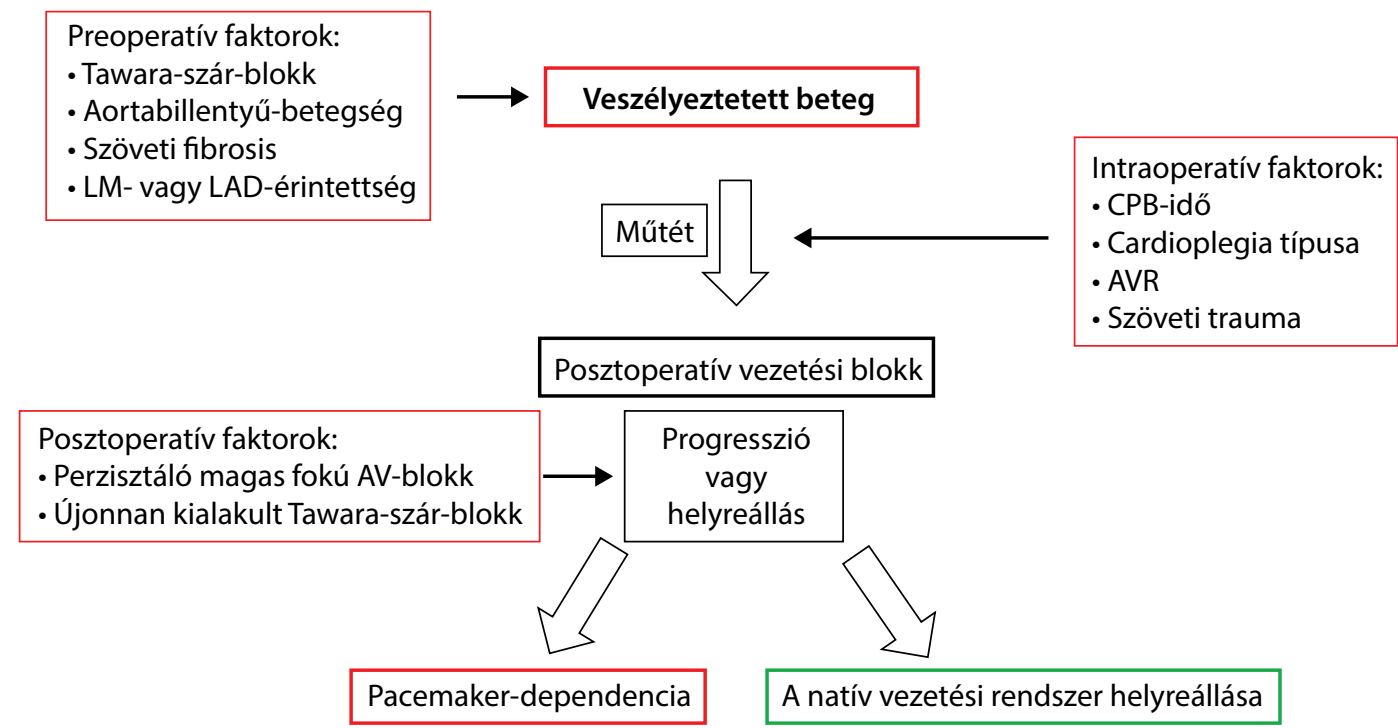

\begin{tabular}{l|l} 
1. ábra & Az állandó pacemaker beültetésére hajlamosító tényezók és a lehetséges kimenetelek Steyers [3] gyüjtése alapján \\
$\mathrm{AV}=$ atrioventricularis; $\mathrm{AVR}=$ aortabillentyú cseréje; $\mathrm{CPB}=$ cardiopulmonary bypass; $\mathrm{LAD}=\mathrm{a}$ bal fötörzs leszálló ága; $\mathrm{LM}=$ bal footörzs
\end{tabular}

\section{Az állandó pacemaker beültetésének kérdése koszorúérmütét után}

Harminc vizsgálat metaanalízise alapján a leggyakoribb vezetési zavar CABG-mútét után az általában jóindulatú és csak átmeneti ideig fennálló jobb-Tawara-szár-blokk. Kialakulásában két fó tényező a myocardialis ischaemia jelenléte és a cardioplegia típusa [14]. Ebben szerepet játszhat, hogy az ingerületvezető rendszer sejtjei szövettanilag különböznek a többi myocytától, és kevésbé tolerálják az ischaemiát, a hyperkalaemiát és a hypothermiát [15]. Az utóbbi lehet az oka annak, hogy meleg cardioplegiás oldat használatát követően alacsonyabb arányban fordulhat elő vezetési zavar, mint hideg oldat esetén (1,7\% vs. 19,6\%) [16]. Koszorúérmútétek során érdemes külön figyelmet szentelni a kardioprotekció ideális kivitelezésére, akár az átmeneti PM-ingerlést igénylő posztoperatív ritmuszavarok is megelőzhetők megfelelő reperfúzióval, és a morbiditás csökkentésében is szerepe lehet a kombinált (anterográd + retrográd) cardioplegiának [17].

Történtek vizsgálatok a posztoperatív ingerületvezetési zavar kialakulásában szerepet játszó prediktor tényezők feltérképezésére. Egy több mint 3500, CABG-mütéten áteső beteget vizsgáló tanulmány esetében, amelynél a betegek 8,15\%-ánál (288 beteg esetében) lépett fel ideiglenes vagy permanens ingerlést igénylő AV-blokk, a következő prediktív tényezőket állapították meg: 60 év feletti kor, női nem, krónikus vesekárosodás, pitvarfibrilláció (PF), III-as vagy IV-es NYHA-stádium, perioperatív akut myocardialis infarctus (AMI), intraaorticus ballonpumpaimplantáció. A fenti jellemzők valamelyikével bíró betegeknél nagyobb eséllyel alakult ki a ritmuszavar. Ugyanezen vizsgálat során mind az elhúzódó kórházi tar- tózkodás esélye, mind a mortalitás aránya szignifikánsan magasabb volt az AV-blokkos csoportban [18]. A fenti adatokat további kutatások is megerősítették, és hangsúlyozták még a hypertensiónak, az áthidalások számának, az aortalefogás és a cardiopulmonary bypass (CPB) idejének, a preoperatív átvezetési zavaroknak és a mútét előtt szedett béta-blokkolóknak a szerepét $[5,16]$.

$\mathrm{Az}$ érintett koszorúerek tekintetében a főtörzs (left main coronary artery $[\mathrm{LM}]$ ) és az elülső leszálló ág (left anterior descending coronary artery [LAD]) szignifikáns szúkülete esetén nagyobb az esély a vezetési zavar kialakulására [19, 20]. Lényeges szempont a LAD stenosisának anatómiája szempontjából, hogy a kamrai sövény felé leadott ága revascularisatióra kerül-e az áthidalás által vagy sem [20]. A myocardium hőmérséklete szintén befolyásolni képes a későbbi vezetési zavarok kialakulását. Egy vizsgálat során a három fő koszorúér területének megfelelően myocardialis hőmérsékletet mértek a mütét alatt, és azt tapasztalták, hogy a később vezetési zavart mutató betegeknél mindegyik szívizomterület hőmérséklete szignifikánsan alacsonyabb volt, a posztoperatív kreatin-kináz-MB (CK-MB) értékei pedig szignifikánsan magasabbak voltak a kontrollcsoport betegeiéinél. A vizsgálat további elemzése szerint a vezetési zavar szempontjából az LM bal körbefutó ága (circumflex coronary artery $[\mathrm{CX}])$ területén mért, szükségtelenül alacsony hőmérséklet és az LM-stenosis jelenléte bizonyult független prediktornak [21]. Bár az optimális myocardiumprotekcióra való törekvés fontos szempont a szívsebészetben, a fentiek alapján arra következtethetünk, hogy a szívizomzat túlzott hútése szintén előidézhet posztoperatív vezetési zavart.

A CABG- és billentyưmuutétek utáni PM-dependenciával kapcsolatos adatgyújtések alátámasztják, hogy az 
előbbi betegcsoportban alacsonyabb az esély a PPMimplantációra. Gordon korai vizsgálatának adatai alapján az izolált CABG-mütéten áteső betegek több mint nyolcszor kisebb eséllyel váltak PM-dependenssé, mint a billentyưvel (is) operáltak [17].

\section{$\mathrm{Az}$ állandó pacemaker beültetésének kérdése billentyümütéteket követően}

Többen beszámoltak arról, hogy az AV-blokk kialakulásának aránya különösen magas billentyümütétek esetén [22-24]. Billentyưmütét után szintén gyakran jelentkező ritmuszavar a sinuscsomó rendellenessége (sinus node dysfunction [SND]) és a lassú kamrai ritmussal járó PF [5]. A billentyűmütétek utáni PM-dependenciában aortabillentyüt érintő beavatkozás során az AV-blokknak, míg mitralis billentyü mütéte esetén a nem AV-blokk típusú ritmuszavaroknak van nagyobb szerepük [25]. Egy nagyrészt billentyüműtéten átesett betegeket vizsgáló cikk alapján a tartós PM-függőség a legmagasabb arányban az AV-blokk kapcsán volt megfigyelhető (41\%), ezt követte az SND (15\%), majd a lassú frekvenciájú PF (9\%) [25].

A hosszú távú PPM-dependencia független prediktorainak meghatározásában szerepet kapott a preoperatív anamnézisben előforduló syncope, a magas testtömegindex, az elhúzódó CPB-idő (>105 min) és az AV-blokk miatti PM-beültetés előfordulása [25]. Másik kutatás alapján aortabillentyü-mútétet követően az időskor (>70 év) és a korábbi aortabillentyư-mütét volt a két kiemelt rizikófaktor a későbbi PPM-beültetésre [24].

A billentyűműtét típusa szintén befolyásolja a későbbi ritmuszavar előfordulásának valószínüségét. Egy nagy esetszámú vizsgálat alapján aortabillentyü-mütét esetén nagyobb a PPM-beültetés valószínüsége, mint mitralis mútétnél, ha pedig a tricuspidalis billentyú is érintett, tovább nő a rizikó. Több billentyüt is érintő műtét esetén a PPM-rizikó a háromszorosára emelkedik, viszont a billentyüplasztika szignifikánsan alacsonyabb mértékben vezet PM-implantációhoz, szemben a billentyú cseréjével [24].

$\mathrm{Az}$ aortabillentyü-mútétek utáni PPM-igény irodalmát Matthews és mtsai ismertetik 30 év meghatározó cikkeiből gyüjtött adatokkal, a fókuszt a lehetséges prediktor faktorokra helyezve. AVR-t követően a PPM-igény $3 \%$ és $11,8 \%$ között mozgott, a PM beültetésének ideje 6,1 és 13 nap között történt meg. Az AVR utáni PPMigény legkifejezettebb prediktora a már korábban is fennálló ingerületvezetési betegség (bal- és jobb-Tawara-szár-blokk, megnyúlt AV-átvezetés, bal anterior hemiblokk) volt, s jelentős kockázatnövekedést mutatott az aortainsufficientia megléte és a korábban elszenvedett AMI. A perioperatív tényezők közül a hosszabb CPBidő mutatkozott a legmeghatározóbbnak [26].

Ami a sebészi technikát illeti, közel ezer fö vizsgálata alapján a tovafutó monofil varrattal történő implantáció esetén a PPM-beültetés esélye a harmadára csökken, és ez a különbség szignifikáns az egyes teflonos öltéstechnikákhoz képest [12]. Az öltés nélküli aortaxenograftok implantációját követő vezetési zavarok aránya alacsonyabb a katéteren keresztüli billentyúbeültetést követő vezetési blokkokhoz képest, a hagyományos AVR-beültetéshez képest viszont magasabb, és ez különösen igaz, ha a mútét előtt is már ismert vezetési zavar állt fenn [27]. A jelenségért valószínűsíthetően a billentyű behelyezésekor kialakuló szöveti kompresszió és a visszamaradó mészdarabok szövetekbe történő penetrációja felelős [28]. A Cleveland Clinic 660000 poszt-AVR-es beteg adatát vizsgáló cikkében tendenciaszerüen magasabb PPM-implantációs arányt találtak biológiai billentyứk beültetése esetén a mechanikussal szemben, de a különbség nem volt szignifikáns [11].

A ritmuszavarok kialakulásában szerepe lehet a billentyưbetegség etiológiájának; AVR-re kerülő betegek esetében az infekciós eredet, a protézisdiszfunkció miatti reoperáció és a bicuspidalis anatómia mindegyike összefüggést mutatott a PM-dependenciával [29]. Elmondhatjuk, hogy míg az aortabillentyü stenosisa esetén fó okként a vezetési rendszer szöveteit roncsoló, azok területére penetráló mész és annak eltávolítása okozhatja a ritmuszavart, addig aortainsufficientia esetén inkább az aortagyök tágulása miatt kialakuló krónikus szöveti feszülés állhat a háttérben. Az utóbbi betegcsoport rizikónövekedéséhez hozzájárulhat, hogy a tágult gyök miatt a betegek nagyobb protézist kapnak, ami szintén hatással lehet a károsodott vezetőképességre [11].

Fontos szempont a billentyümütétet követően a betegek ritmuszavar kapcsán történő utánkövetése. AVR-t követően a későbbiekben is kialakulhat vezetési zavar, és még ha a mútét után rövid távon nem volt is szükség rá, a PPM-beültetés aránya az idő előrehaladtával nő [30]. Azokban a betegekben, akiknél a mütét utáni AV-blokk az első 30 posztoperatív napon belül megszűnt, a hosszú távú, átlagosan 4,1 éves utánkövetés során 26\%-ban ismét visszatért [31]. Ez ismételten az érintett betegek szoros utánkövetésére hívja fel a figyelmet.

\section{A European Society of Cardiology (ESC) 2013. évi ajánlásainak ismertetése}

\section{(2. táblázat)}

Az ESC ajánlása szúkszavúan nyilatkozik a témában, mindössze arról tesz említést, hogy szívmütét után, állandó PM implantációját megelőzően ajánlott az 5-7 napos várakozás [32]. Az aorta- és/vagy mitralis billentyű mưtétét követő első 24 órában fellépő és azt követően 48 órán át fennmaradó $\mathrm{AV}$-blokk $1-2$ héten belüli megszünése nem valószínú, így az elhúzódó kórházi tartózkodás megelőzésére megfontolandó az állandó PM korábbi implantációja [22]. A fenti megközelítés megfontolandó alacsony frekvenciájú pótritmussal bíró $\mathrm{AV}$ blokk esetén is [32]. A késői nyomon követés alapján a 
A European Society of Cardiology állandó pacemaker szívmútét utáni implantációjára vonatkozó ajánlásai

\begin{tabular}{|c|c|c|c|}
\hline Osztály & Szint & Ajánlás & \\
\hline I. & $\mathrm{C}$ & $\begin{array}{l}\text { Szívmütétet követő, } \\
\text { magas fokú vagy } \\
\text { komplett AV-blokk }\end{array}$ & $\begin{array}{l}\text { Legfeljebb } 7 \text { napos obszervá- } \\
\text { ció keretében szükséges } \\
\text { felmérni és értékelni azt, hogy } \\
\text { a ritmuszavar átmeneti-e vagy } \\
\text { sem; azonban alacsony } \\
\text { escape-ritmussal bíró komplett } \\
\text { AV-blokk esetén ez } \\
\text { a megfigyelési időszak } \\
\text { lerövidíthető, mivel } \\
\text { a ritmuszavar megszúnése } \\
\text { nem valószínű. }\end{array}$ \\
\hline I. & $\mathrm{C}$ & $\begin{array}{l}\text { Szívműtétet követő } \\
\text { sinuscsomó-disz- } \\
\text { funkció }\end{array}$ & $\begin{array}{l}\text { Az obszerváció időtartama } \\
\text { a ritmuszavar feloldódásának } \\
\text { függvényében } 5 \text { naptól néhány } \\
\text { hétig tart. }\end{array}$ \\
\hline
\end{tabular}

$\mathrm{AV}=$ atrioventricularis

PM-függő betegek 30-40\%-ánál a sinuscsomó rendellenessége miatt, 65-100\%-ánál AV-átvezetési zavar következtében történik a PPM-implantáció [32, 33].

\section{Az American College of Cardiology (ACC) - American Heart Association (AHA) - Heart Rhythm Society (HRS) 2018. évi ajánlásainak ismertetése (3. táblázat)}

\section{Koszorúrmütét}

Az ingervezetési zavarok előfordulása izolált CABG-mútétet követően $2 \%$ és $58 \%$ között változik, és olyan kíséró tényezőkhöz kapcsolódik, mint például a szív krónikus degeneratív betegsége, az ingervezető rendszer közvetlen műtéti károsodása, a myocardialis ischaemia vagy az elégtelen myocardialis protekció $[19,34]$. Ha a bradycardia kialakulását okozó vezetési rendellenesség már a mútét előtt fennállt, akkor általában nem múlik el koszorúérmútét után sem [35]. Az ACC/AHA/HRS ajánlása alapján a PPM-beültetés időpontjáról széles körű vizsgálatok adatai nem állnak rendelkezésre, az adott osztály egyéni tapasztalatán alapul, de CABG után rendszerint a mútét után 5-7 nappal mondható észszerünek.

\section{Billentyümütétek}

Észak-Amerikában az évi, megközelítőleg 100 000, billentyümütéten átesett beteg $\mathrm{kb}$. 5\%-ának volt szüksége PPM beültetésére az elbocsátás előtt [23]. A billentyümütétet követő PPM-implantációra hajlamosító tényezőként említik a preoperatív jobb- vagy bal-Tawara-szárblokkot, a többszörös billentyưmútétet (különös tekintettel a tricuspidalis billentyưre), azt, ha a preoperatív EKG-n a PR-intervallum>200 ms, a korábbi billentyưmútétet, a 70 évnél idősebb kort, a reoperációt, az elhúzódó aortalefogási időt és a preoperatív sinusrhyth-
3. táblázat Az American College of Cardiology/American Heart Association/Heart Rhythm Society állandó pacemaker szívmútét utáni implantációjára vonatkozó ajánlása

\begin{tabular}{lll}
\hline Osztály & Szint & Ajánlás \\
\hline CABG & & \\
\hline I. & B & $\begin{array}{l}\text { Amennyiben az újonnan kialakult posztoperatív } \\
\text { sinus /AV-csomó-blokkhoz perzisztáló tünetek } \\
\end{array}$ \\
& $\begin{array}{l}\text { vagy hemodinamikai instabilitás társul, amelyek } \\
\text { a CABG-mútétet követően nem szûnnek, ajánlott } \\
\text { az állandó PM elbocsátás előtti implantációja. }\end{array}$ \\
\hline II/b & C & $\begin{array}{l}\text { Azon CABG-mútéten áteső betegek esetében, } \\
\text { akiknek a jövóben valószínúleg CRT-PM-re vagy } \\
\text { kamrai ingerlésre lesz szükségük, az állandó bal } \\
\text { kamrai epicardialis elektróda intraoperatív behelye- } \\
\text { zése mérlegelendó. }\end{array}$ \\
\hline
\end{tabular}

Aortabillentyü

I. B Amennyiben az újonnan kialakult posztoperatíy sinus/AV-csomó-blokkhoz perzisztáló tünetek vagy hemodinamikai instabilitás társul, amelyek az aortabillentyű-műtétet követően nem szűnnek, ajánlott az állandó PM elbocsátás előtti implantációja.

II/b C Azon aortabillentyú-mútéten áteső betegek esetében, akiknek a jövőben valószínúleg CRT-PM re vagy kamrai ingerlésre lesz szükségük, az állandó bal kamrai epicardialis elektróda intraoperatív behelyezése mérlegelendő.

Mitralis billentyú

I. B Amennyiben az újonnan kialakult posztoperatív sinus/AV-csomó-blokkhoz perzisztáló tünetek vagy hemodinamikai instabilitás társul, amelyek a mitralisbillentyü-mütétet követően nem szűnnek, ajánlott az állandó PM elbocsátás előtti implantációja.

II/b C Azon mitralisbillentyű-műtéten áteső betegek esetében, akiknek a jövóben valószínúleg CRT-PM-re vagy kamrai ingerlésre lesz szükségük, az állandó bal kamrai epicardialis elektróda intraoperatív behelyezése mérlegelendő.

Tricuspidalis billentyú

I. B Amennyiben az újonnan kialakult posztoperatív sinus/AV-csomó-blokkhoz perzisztáló tünetek vagy hemodinamikai instabilitás társul, amelyek a tricuspidalisbillentyü-mútétet követően nem szűnnek, ajánlott az állandó PM elbocsátás előtti implantációja.

II/a C Azon tricuspidalisbillentyü-mütéten áteső betegek esetében, akik nagy rizikóval bírnak a posztoperatív AV-blokkot illetően, az állandó epicardialis elektródák intraoperatív behelyezése indokolt.

$\mathrm{AV}=$ atrioventricularis; $\mathrm{CABG}=$ koszorúér-áthidalás $; \mathrm{CRT}=$ reszink ronizációs terápia; $\mathrm{PM}=$ pacemaker

mus hiányát [24]. A PM-beültetés széles határok között változik, és függ a mútét típusától: mitralis billentyü esetén átlagosan $3,5 \%$, aortabillentyü esetén $5,1 \%$, a tricuspidalis billentyü esetén $12 \%$, aorta + mitralis esetén $10 \%$, mitralis és tricuspidalis kombinált mütét esetén 16\%, illetve az aorta- + mitralis + tricuspidalis billentyút együtt érintő mütét alapján $25 \%[13,24]$. 


\section{$\mathrm{Az}$ aortabillentyüt érintő mütétek}

$\mathrm{Az}$ aortabillentyú-mútétet követően a leggyakrabban a His-köteg sérülése okozza az ingerületvezetési problémát, amely létrejöhet az aortagyök mésztelenítése, szöveti ödéma vagy túl mélyre helyezett varratok következtében. Aortabillantyứ-mútét után a PPM-implantáció aránya 3\% és 8,5\% közötti, a legnagyobb rizikóval a mútét előtt is ingerületvezetési zavarokkal élő́k bírnak [36]. A betegek döntő többségénél nem áll helyre az AV-vezetési zavar a késóbbiekben, és azoknál, akik AVR-t követően 30 napon belül PM-et kaptak, magasabb a hosszú távú mortalitás aránya $[10,37]$. Mivel az aortabillentyú a His-köteg közelében helyezkedik el, a mitralis billentyú viszont leginkább az AV-csomóhoz van közel, az aortabillentyú mútétét követő AV-blokk esetében az élettani ingerületvezetés visszatérése kevésbé valószínú, így ilyenkor tanácsos hamarabb indikálni a PPM beültetését [37]. Ez alapján ha az újonnan fellépett AV-blokk nem szúnik meg, és hemodinamikailag jelentős, tünetekkel járó bradycardia mutatkozik, az osztályos elbocsátás előtt PPMimplantációt szükséges végezni [38]. Az ACC/AHA/ HRS ajánlása alapján a PPM-beültetés konkrét időpontjáról széles körú vizsgálatok adatai nem állnak rendelkezésre, az adott osztály egyéni tapasztalatán alapul, de aortabillentyú-mútét után rendszerint 3-5 nappal mondható észszerünek.

\section{A mitralis billentyút érintő mütétek}

MVP (mitral valvuloplasty) vagy MVR-mútétet követóen 23,5\%-ban számoltak be újonnan fellépó AV-blokkról. Egy patológiai témájú vizsgálatban 55 , szívmútéten át nem esett, elhunyt beteg szívén vizsgálták az AV-csomó, az azt ellátó nodalis artéria és a mitralis anulus anatómiájának kapcsolatát. 23\%-ban találtak az anulus közelében futó, az AV-csomót ellátó artériát, amelynek feltételezhető a mútét alatti sérülése és ennek következtében ingerületvezetési zavar fellépése [39]. A mitralis billentyư mútétei utáni PPM-igény 1\% és 9\% között változik $[40,41]$. Gyakoriságát befolyásolhatja a mútét típusa, és alacsonyabb lehet MVP után, mivel megszakított anuloplastica végzésével elkerülhetó az AV nodalis artéria sérülése [40, 41]. Ha a perioperatíve újonnan fellépett AV-blokk vagy SND nem mutat javulást, és hemodinamikailag jelentős, tünetekkel járó bradycardia mutatkozik, ajánlott a PPMimplantáció elvégzése, lehetőleg még az osztályos elbocsátás előtt. Mivel a mitralis billentyú mútéte során inkább sérül az AV-csomó, mint a His-köteg, ajánlott tovább kivárni, és valamivel később indikálni a PPM beültetését [40]. Az ACC/AHA/HRS ajánlása alapján a PPM-beültetés konkrét időpontjáról széles körű vizsgálatok adatai nem állnak rendelkezésre, az adott osztály egyéni tapasztalatán alapul, de mitralis billentyú mútéte után rendszerint 5-7 nappal mondható észszerúnek.

\section{A tricuspidalis billentyút érintő mütétek}

$\mathrm{Az}$ AV-csomó anatómiailag szorosan kapcsolódik a tricuspidalis billentyúhöz, annak elülső és septalis vitorlája között helyezkedik el. Ez az anatómiai helyzet fogékonynyá teszi az AV-csomót a mútét során szerzett sérülésekre. Ennek elkerülése érdekében több sebészi technika került kifejlesztésre, például a megszakított tricuspidalis ringek kialakítása, amelyek rést hagynak az elülső és a septalis vitorla között. A tricuspidalis billentyú plasztikáját követően a PPM beültetésének igénye mindössze $2,3 \%$ volt [41]. Mivel a billentyú izolált mútéte ritka, a pontos arányt nehéz megállapítani, jóval magasabb, akár $22 \%$-os adatot is közöltek [42]. A vezetési rendellenességek kezelését bonyolítja, hogy a transvenosus elektródák a tricuspidalis pozícióba beültetett mechanikus billentyúkön át nem vezethetők el, és a plasztikázott vagy natív billentyú záródását is részben gátolják. A natív billentyưn át elvezetett jobb kamrai elektróda is jelentős regurgitatiót okoz a betegek mintegy negyedében, tricuspidalis plasztika után a mérsékelt vagy súlyos insufficientia gyakorisága pedig $42 \%$ [43]. A regurgitatio elkerülése érdekében az elektródát ajánlott az anterior és a septalis vitorlák között elvezetni. A TVP-n vagy TVR-en áteső betegeknek a posztoperatív AV-blokk szempontjából nagy kockázatú csoportjában fontolóra kell venni az állandó epicardialis elektróda szívmútét során történő behelyezését, tekintettel az epicardialis elektróda későbbi használhatatlanságára pedig érdemes több elektródát (nonapicalis, jobb kamrai, lateralis bal kamrai, pitvari) is implantálni [44]. Szüksség esetén ezek a lezárt epicardialis elektródák használhatóvá válnak, más esetben pedig a sinus coronariuson keresztüli implantáció jön számításba. Az ACC/AHA/HRS ajánlása alapján a PPM-beültetés konkrét időpontjáról széles körú vizsgálatok adatai nem állnak rendelkezésre, az adott osztály egyéni tapasztalatán alapul, de tricuspidalis billentyú mütéte után rendszerint 3-5 nappal mondható észszerúnek.

\section{Módszer}

A Zala Megyei Szent Rafael Kórház Szívsebészetén 2014. 01. 01. és 2018. 12. 31. között nyitott szívmútéten átesett 2735 beteg adatait gyüjtöttük és elemeztük retrospektív módon. Minden szívmútét során egy vagy több ideiglenes PM-elektróda (úgynevezett pull-out elektróda) került felhelyezésre a jobb kamra elülső-alsó felszínére vagy a jobb fülcsére. Ezek az elektródák rutinszerüen az 5. posztoperatív napon kerültek eltávolításra. Az elektródák eltávolítására késóbb került sor fennálló ritmuszavar gyógyszeres kezelése esetén. Amennyiben PPM-implantációra került sor, ezután az ideiglenes elektródák szintén eltávolításra kerültek. A vizsgálat során azonosítottuk azokat a betegeket, akiknél a mütét utáni 30 napon belül PPM-implantációra került sor. Megvizsgáltuk a betegek anamnesztikus adatait, a mútéti adatokat és a posztoperatív adatokat. Az alacsony betegszám miatt alapos statisztikai elemzésre nem volt lehetőségünk. Minden beteg utánkövetése egy évig tartott. Az utánkövetés a betegek ambuláns visszahívásával és az implantált PM-ek telemetriás vizsgálatával történt. 


\section{Eredmények}

A fenti időszak során 15 esetben $(0,55 \%)$ volt szükség PPM implantációjára a posztoperatív 30 napon belül. A 68 éves átlagos életkorú, 55\%-os átlagos ejekciós frakcióval bíró betegek közül 7 bírt preoperatív PF-fel, 3 pedig bal-Tawara-szár-blokkal. 12 beteg szorult béta-blokkoló terápiára a mütét előtt, és 5 beteg szenvedett ischaemiás szívbetegségben. 9 beteg aortabillentyü-implantáción vagy -plasztikán, 1 mitralis plasztikán, 1 koszorúérmútéten, további 4 pedig kombinált mútéten esett át. $\mathrm{Az}$ aortalefogás ideje átlagosan 81,6 (27-172) perc, a CPBidő 117 (59-220) perc volt. A betegek 4,3 (1,7-19,8) napot töltöttek az ITO-n. 10 betegnek volt már a mütőben PM-igénye, a PPM-implantáció pedig átlagosan 6,6 (0-22) nappal a mütét után történt. A PM-beültetés indikációja 11 esetben teljes AV-blokk, 2 esetben a mütét idejéig nem ismert carotis sinus hyperaesthesia, 1-1 esetben pedig bradyarrhythmia absoluta vagy asystolia volt.
Vizsgálatunk során összesen 4 beteg hunyt el, 3 az egyéves utánkövetés alatt, l pedig az utánkövetés idején túl. Egy hónapon belüli kórházi halálozás egy esetben történt. A halál oka minden esetben keringési elégtelenség volt. Egyik esetben sem volt szoros összefüggés a halál és a PPM-implantáció szükségessége között. A késői, egyéves utánkövetés szerint 6 beteg $(54,5 \%)$ volt még mindig PM-dependens, míg a többieknél a kontroll- és a telemetriás vizsgálat kapcsán nem volt detektálható PMaktivitás. Adatainkat a 4. táblázat szemlélteti.

\section{Megbeszélés}

A fenti időszak alatt az osztályunkon tapasztalt, 0,55\%os PPM-implantációs arány alacsonynak mondható, de nem egyedi. Egy 16 éves periódus alatt motoros CABGmütéten áteső 3532 beteget vizsgáló tanulmányban mindössze 8 beteg (a teljes populáció $0,23 \%$-a) esetében

4. táblázat | Betegeink anamnesztikus adatai és perioperatív változói

\begin{tabular}{|c|c|c|c|c|c|c|c|c|c|c|c|c|c|}
\hline Nem & $\begin{array}{l}\text { Kor } \\
\text { (év) }\end{array}$ & $\begin{array}{l}\text { Pre- } \\
\text { operatív } \\
\text { PF }\end{array}$ & $\begin{array}{l}\text { Preoperatív } \\
\text { béta-blok- } \\
\text { koló }\end{array}$ & $\begin{array}{l}\text { Pre- } \\
\text { operatív } \\
\text { EF }(\%)\end{array}$ & $\begin{array}{l}\text { Mütét- } \\
\text { típus }\end{array}$ & $\begin{array}{l}\text { Aorta- } \\
\text { lefogás } \\
(\min )\end{array}$ & $\begin{array}{l}\text { ECC } \\
(\min )\end{array}$ & $\begin{array}{l}\text { PM-igény } \\
\text { mútőben }\end{array}$ & $\begin{array}{l}\text { PM- } \\
\text { implantá- } \\
\text { ció (nap) }\end{array}$ & PM-indikáció & $\begin{array}{l}\text { Egyéves } \\
\text { PM- } \\
\text { dependencia }\end{array}$ & $\begin{array}{l}\text { ITO } \\
\text { (óra) }\end{array}$ & Exit \\
\hline 1. Nő & 77 & Igen & Igen & 45 & $\begin{array}{l}\mathrm{AVR}+ \\
\mathrm{MVR}\end{array}$ & 122 & 140 & - & 12 & Asystolia & Igen & 79 & Igen \\
\hline 2. Nö & 66 & - & - & 55 & AVR & 68 & 87 & Igen & 5 & $\begin{array}{l}\text { Teljes } \\
\text { AV-blokk }\end{array}$ & Igen & 139 & - \\
\hline 3. Férfi & 64 & Igen & Igen & 70 & AVR & 125 & 145 & - & 7 & $\begin{array}{l}\text { Carotis sinus } \\
\text { hyperaesthesia }\end{array}$ & - & 46 & - \\
\hline 4. Férfi & 67 & Igen & Igen & 35 & AVR & 172 & 220 & - & 12 & $\begin{array}{l}\text { Teljes } \\
\text { AV-blokk }\end{array}$ & - & 116 & - \\
\hline 5. Férfi & 82 & Igen & - & 69 & MVP & 107 & 165 & Igen & 0 & $\begin{array}{l}\text { Teljes } \\
\text { AV-blokk }\end{array}$ & - & 42 & - \\
\hline 6. Férfi & 79 & Igen & Igen & 45 & $\begin{array}{l}\mathrm{AVR}+ \\
\mathrm{TVP}\end{array}$ & 42 & 106 & Igen & 2 & $\begin{array}{l}\text { Teljes } \\
\text { AV-blokk }\end{array}$ & Igen & 67 & - \\
\hline 7. Nô & 52 & - & Igen & 55 & AVP & 38 & 59 & - & 2 & $\begin{array}{l}\text { Teljes } \\
\text { AV-blokk }\end{array}$ & Igen & 68 & - \\
\hline 8. Férfi & 72 & - & Igen & 65 & AVR & 58 & 78 & Igen & 5 & $\begin{array}{l}\text { Teljes } \\
\text { AV-blokk }\end{array}$ & Igen & 117 & - \\
\hline 9. Férfi & 69 & - & Igen & 58 & CABG & 27 & 68 & Igen & 6 & $\begin{array}{l}\text { Carotis sinus } \\
\text { hyperaesthesia }\end{array}$ & - & 49 & - \\
\hline 10. Nö & 65 & - & Igen & 48 & AVR & 47 & 60 & Igen & 4 & $\begin{array}{l}\text { Teljes } \\
\text { AV-blokk }\end{array}$ & - & 102 & - \\
\hline 11. Férfi & 49 & - & - & 30 & $\begin{array}{l}\mathrm{AVR}+ \\
\mathrm{CABG}\end{array}$ & 74 & 182 & - & 13 & $\begin{array}{l}\text { Teljes } \\
\text { AV-blokk }\end{array}$ & - & 476 & Igen \\
\hline 12. Férfi & 78 & Igen & Igen & 60 & $\begin{array}{l}\mathrm{MVP}+ \\
\mathrm{CABG}\end{array}$ & 83 & 100 & Igen & 22 & $\begin{array}{l}\text { Bradyarrhyth- } \\
\text { mia absoluta }\end{array}$ & - & 46 & Igen \\
\hline 13. Férfi & 80 & - & Igen & 66 & AVR & 95 & 120 & Igen & 2 & $\begin{array}{l}\text { Teljes } \\
\text { AV-blokk }\end{array}$ & - & 44 & Igen \\
\hline 14. Férfi & 59 & Igen & Igen & 60 & AVR & 60 & 97 & Igen & 5 & $\begin{array}{l}\text { Teljes } \\
\text { AV-blokk }\end{array}$ & Igen & 118 & - \\
\hline 15. Nö & 55 & - & Igen & 65 & AVR & 107 & 125 & Igen & 2 & $\begin{array}{l}\text { Teljes } \\
\text { AV-blokk }\end{array}$ & - & 43 & - \\
\hline
\end{tabular}

AVP = aortabillentyű plasztikája; AVR = aortabillentyű cseréje; CABG = koszorúér-áthidalás; ECC = extracorporeal circulation; EF = ejekciós frakció; ITO = Intenzív Terápiás Osztály; $\mathrm{MVP}=$ mitralis billentyű plasztikája $; \mathrm{MVR}=$ mitralis billentyű cseréje; $\mathrm{PF}=$ pitvarfibrilláció; PM = pacemaker; TVP = tricuspidalis billentyü plasztikája 
történt PPM-beültetés, de más vizsgálatok esetében is állapítottak meg alacsonyabbnak mondható, 0,49\%-os és $0,73 \%$-os arányt $[5,17,18]$. Amint az a guideline-ok ismertetéséből kiderült, nem létezik evidenciaalapú ajánlás a PPM-beültetés időzítésére, de észszerűnek a 3-7. posztoperatív nap időszakát tartják. Osztályunkon a PPM-implantáció átlagosan 6,6 nappal a mútét után történt. 9 beteg esetében történt meg a PPM-beültetés az 1-7. posztoperatív nap valamelyikén, egy dilatativ cardiomyopathiában szenvedő beteg esetében pedig már a primer műtét során. További 4 beteg kapcsán a beültetés egy héten túl történt meg, 1 esetben azért, mert a ritmuszavar a későbbiekben jelentkezett, 3 esetben pedig még az ITO-n centrális vénán keresztüli ideiglenes PMelektróda behelyezése történt, amellyel a betegek átmenetileg biztonsággal kezelhetővé váltak. Pires és Merin kutatócsoportja szerint a beültetésről szóló döntést a 4-5. posztoperatív napon szükséges meghozni, mivel ezt követően az AV-blokk rendszerint már nem szűnik, így a betegek immobilizációja és a kórházi tartózkodás elhúzódik; más eredmények alapján lehet és érdemes várni a 7. posztoperatív napig $[16,24,33]$. Patel és munkacsoportja bizonyították, hogy a posztoperatív időszakban korai időpontban implantált PPM-ek többsége is magasabb ingerlési arányt mutat, vagyis valóban szükséges volt a beültetés, ezzel szemben a kevéssel később beültetett PPM-ek egy jelentős része alacsony ingerlési arányt mutatott, vagyis nem mindig volt a háttérben PM-függő ritmuszavar. Vizsgálatukban a mútéttől a PPM-implantációig eltelt idő szignifikánsan hosszabb volt az alacsony ingerlési arányt mutató csoportban $(8,1$ nap vs. 6,2 nap, $\mathrm{p}=0,003)$, vagyis a szívmútét és a PPM implantációja között eltelt hosszabb idő nem volt összefüggésben a PPM alkalmazásának hosszú távú szükségességével [45].

Osztályunkon a posztoperatív szövődményektől mentes betegek protokoll szerint az első-második posztoperatív napon hagyják el az ITO-t, 15 PPM-es betegünk azonban hosszabb ideig, átlagosan 4,3 (1,7-19,8) napig igényelt ITO-s ápolást. 8 beteg esetében elsôsorban a PPM-beültetést igénylő ritmuszavar határozta meg a posztoperatív szak elhúzódását, a másik 7 esetben azonban fennállt egyéb, erre utaló komplikáció is. Az alacsony esetszám miatt a preoperatív változók és a PPM-implantáció között összefüggést nem tudtunk felállítani, a 3 betegnél fennálló bal-Tawara-szár-blokk ilyen irányú szerepét azonban feltételezhetjük. Költségekről szóló kalkulációt nem végeztünk, és a kis elemszám miatt mindössze teoretikusan állíthatjuk, hogy a fentiek tekintetében a PPM-dependens betegek kezelése valószínúleg költségesebb volt. Itt utalunk ismételten arra, hogy a szívmútét után PPM-beültetésre váró betegeknek rendszerint hosszabb a hospitalizációs idejük, ami a kezelési költségek növekedéséhez vezet [11].

Ahogy az ajánlások értelmezéséből kiderült, részletes iránymutatás nem létezik a PPM-implantációra, így saját betegeink esetében is az egyéni elbírálás, a kardiológusokkal való konzultáció volt a döntő. Egyes szívsebésze- teken protokoll alkalmazásával álltak elő. Egy kanadai vizsgálatban a PM-függőséget olyan SND, AV-blokk vagy lassú frekvenciával bíró PF képében határozták meg, amelynél a VVI-módba állított PM 30/min-nél alacsonyabbra állított frekvencia esetén aktivitást mutatott; egy másik vizsgálat a fenti feltételek mellett 50/ min-es frekvenciát határozott meg, vagy a $40 /$ min-re igazított frekvencia mellett 40 másodperc alatt észlelt folyamatos PM-ritmus alapján állapították meg a dependenciát [25, 33]. Nagy esetszámú tanulmány alapján pontos rizikóbecslő pontrendszer is készült; közel 5000, szívmütéten átesett beteg adatai alapján állítottak fel score-rendszert a következők szerint: 2 pontot ért a preoperatív jobb-Tawara-szár-blokk és a tricuspidalis billentyưt érintő kombinált mútét, további 1-1 pontot a preoperatív bal-Tawara-szár-blokk (left bundle branch block [LBBB]) és a 200 ms-nál hosszabb PR-idő, a tricuspidalis billentyüt nem érintő kombinált mütét, továbbá a 70 év feletti kor és a korábbi billentyưmütét. A pontozás alapján felállítottak három rizikócsoportot: alacsony (0-1 pont), közepes ( $2-3$ pont) és magas rizikó ( $\geq 4$ pont). A fenti rizikóbecslés alapján a PPM-implantáció aránya a három csoportban $3,6 \%, 9,8 \%$ és $25 \%$ volt [24].

Betegeink preoperatív ritmuszavarait illetően dominált a PF: 15-ből 7 betegünk bírt a mütét előtt ezzel a ritmuszavarral. Más tanulmányok magasabb prediktív értéket tulajdonítanak a preoperatív jobb- vagy balTawara-szár-blokknak, a bifascicularis blokknak, de a megnyúlt PR-időt vagy a széles QRS-szakaszt is a PF elé sorolják, sőt született olyan tanulmány, amelyben a preoperatív ritmuszavar jelenléte az aortainsufficientia mellett a PPM-beültetés egyetlen független prediktora volt $[24,36]$. Másrészről van közlemény, amelyben nem találtak összefüggést a mütét előtt fennálló és a perioperatív ritmuszavarok kialakulása között [29]. Adataink szerint a PPM-beültetésre került betegek nagy része béta-blokkoló kezelést kapott. Megoszlanak a vélemények a mútét előtt szedett negatív chronotrop szerekrôl, egyesek összefüggésbe hozták őket későbbi vezetési zavarokkal, mások cáfolták ezt a tézist [16, 29].

A késői utánkövetés során a PPM-es betegeknek mindössze kevéssel több mint a fele volt valóban PM-dependens. Beszámolnak arról, hogy az elektív szívmútétre (CABG és billentyú) kerülő betegek harmada már röviddel a mútét után sem mondható PM-függőnek, és ez az arány hosszabb távon szintén csak nőhet [46]. Ezzel szemben AVR-mütéten átesett betegeknél a PPM-függőség hosszú távon is magas arányban fennmarad. Baraki és Ribeiro adatai alapján az AVR-t követő PM-dependencia aránya hosszú távon is $64 \%$, illetve $90 \%$ maradt $[10,29]$. Nincs pontos adatunk a PM-dependencia okáról a hosszú távon is PM-függő betegeknél, az irodalomban azonban találtunk erre vonatkozó utalást. Merin közli, hogy egy vegyes (de döntően CABG-n átesett), 5000 fós szívsebészeti populációban, amelyben a perioperatív időszakban PPM-et igénylő betegek 63\%-a maradt PM-függő évekkel a műtét után is, a hosszú távú 
PPM-dependencia két fó prediktora a preoperatív LBBB és a perioperatív harmadfokú AV-blokk volt [33].

A vizsgálatunkban szereplő betegek közül 3 hunyt el az egyéves utánkövetésen belül, összesen pedig 4 beteg hunyt el. A Wiggins és mtsai által vizsgált, közel 40000 beteg közül beültethető elektromos eszköz implantációján átesett 1608 beteg $(4,1 \%)$ túlélése a korai posztoperatív időszakban szignifikánsan javult, míg a késői posztoperatív utánkövetés során szignifikáns romlást mutatott a kontrollcsoporthoz képest [47]. Más eredmények szerint, miután a hosszú távú mortalitási eredményeket a korhoz, a preoperatív rizikóhoz és a mütét típusához igazították, azt tapasztalták, hogy nincs szignifikáns különbség a mortalitásban a PPM-beültetésen átesett és a PM-et nem kapó betegek között [48].

\section{Következtetések}

Összességében elmondhatjuk, hogy a perioperatív időszakban jelentkező ritmuszavarok a szívsebészeti beavatkozások gyakori és komoly következményekkel járó szövődményei, amelyek nagyban nehezítik a betegek gyors felépülését, terhet rónak a betegellátásra, és komoly költségtöbbletet jelentenek. A PPM-beültetés aránya magasabb a billentyümútéteket követően, mint CABG után, és a beültetett billentyúk számával növekszik. A PPMbeültetés szükségességének aránya a Zala Megyei Szent Rafael Kórház Szívsebészetén alacsonynak mondható, a késői utánkövetés eredményei szerint azonban a betegeknek így is csak egy része mondható valóban PMdependensnek. Adataink közel azonos eredményt mutatnak a nemzetközi tanulmányok adataival, ám a guideline-ok inkább hozzávetőleges iránymutatást adnak a probléma kezelésére. A fentiek alapján, nagy betegszámú vizsgálat adatainak feldolgozásával, prospektív adatgyưjtés mellett megfontolandó lenne a PPM-implantációra vonatkozó részletes protokoll kidolgozása. Egy esetleges rizikóbecslő rendszer segítségünkre lehetne a nagy valószínûséggel PM-implantációra kerülő betegek esetében (nagyon rossz bal kamrai funkció, dilatált kamrák, aszinkrón falmozgás) a mưtét során történó állandó epicardialis elektróda behelyezésében, amely a későbbiekben biztonsággal alkalmazható a megfelelő eszközzel (cardiac resynchronization therapy [CRT], implantable cardioverter defibrillator [ICD]) összekapcsolva. Egyedi esetekben a PPM-beültetés szempontjából nagy rizikójú betegeknél a mütét megtervezésekor is figyelembe lehetne venni a kapott információkat (billentyücsere helyett kiemelt törekvés plasztikára, tovafutó öltés használata, revascularisatiós lehetőségek, a legmegfelelőbb kardioprotekció szerepe). Az ismertetett hajlamosító tényezőkkel bíró betegeket (külön tekintettel az újonnan fellépett perioperatív ritmuszavarokra) a hirtelen halál és az egyéb szövődmények elkerülése érdekében szigorú megfigyelés alatt szükséges tartani a felépülés/PPM-beültetés bekövetkezéséig (folyamatos EKG-monitorizálás, szükség esetén Holter-vizsgálat).
Anyagi támogatás: A cikk megírásához anyagi támogatásban egyik szerző sem részesült.

Szerzői munkamegosztás: T. R.: A cikk megírása. R. A.: Véleményezés szívsebészeti szempontból, a saját adatok kiértékelésében való részvétel. T. T., R. Á.: Véleményezés kardiológiai szempontból, a publikációk kiválasztása az irodalmi áttekintéshez. A cikk végleges változatát valamennyi szerző elolvasta és jóváhagyta.

Érdekeltségek: A szerzőknek nincsenek érdekeltségeik.

\section{Irodalom}

[1] Yater W, Cornell, V. Heart block due to calcareous lesions of the bundle of his: review and report of a case with detailed histopathologic study. Ann Intern Med. 1935; 8: 777-789.

[2] Sellers R, Kanjuh V, Eliot RS, et al. Complete heart block following aortic and mitral valve replacement: anatomic basis, prevention and management. Circulation 1963; $28: 801$.

[3] Steyers CM 3rd, Khera R, Bhave P. Pacemaker dependency after cardiac surgery: a systematic review of current evidence. PLoS ONE $2015 ; 10$ : e0140340.

[4] Reade MC. Temporary epicardial pacing after cardiac surgery: a practical review. Part 1: general considerations in the management of epicardial pacing. Anaesthesia 2007; 62: 264-271. [Correction: Anaesthesia 2007; 62: 644.]

[5] Emlein G, Huang SK, Pires LA, et al. Prolonged bradyarrhythmias after isolated coronary artery bypass graft surgery. Am Heart J. 1993; 126: 1084-1090.

[6] Reade MC. Temporary epicardial pacing after cardiac surgery: a practical review. Part 2: selection of epicardial pacing modes and troubleshooting. Anaesthesia 2007; 62: 364-373.

[7] Jaeger FJ, Trohman RG, Brener S, et al. Permanent pacing following repeat cardiac valve surgery. Am J Cardiol. 1994; 74: 505-507.

[8] Kusumoto FM, Schoenfeld MH, Barrett C, et al. 2018 ACC/ AHA/HRS Guideline on the evaluation and management of patients with bradycardia and cardiac conduction delay: a report of the American College of Cardiology/American Heart Association Task Force on clinical practice guidelines and the Heart Rhythm Society. Circulation 2019; 140: e382-e482. [Correction: Circulation 2019; 140: e506-e508.]

[9] Brignole M, Auricchio A, Baron-Esquivias G, et al. 2013 ESC Guidelines on cardiac pacing and cardiac resynchronization therapy: the Task Force on cardiac pacing and resynchronization therapy of the European Society of Cardiology (ESC). Developed in collaboration with the European Heart Rhythm Association (EHRA). Europace 2013; 15: 1070-1118.

[10] Baraki H, Al Ahmad A, Jeng-Singh S, et al. Pacemaker dependency after isolated aortic valve replacement: do conductance disorders recover over time? Interact Cardiovasc Thorac Surg. 2013; 16: 476-481.

[11] Robich MP, Schiltz NK, Johnston DR, et al. Risk factors and outcomes of patients requiring a permanent pacemaker after aortic valve replacement in the United States. J Card Surg. 2016; 31: 476-485.

[12] Niclauss L, Delay D, Pfister R, et al. Low pacemaker incidence with continuous-sutured valves: a retrospective analysis. Asian Cardiovasc Thorac Ann. 2017; 25: 350-356.

[13] Leyva F, Qiu T, McNulty D, et al. Long-term requirement for pacemaker implantation after cardiac valve replacement surgery. Heart Rhythm 2017; 14: 529-534.

[14] Kumbhani DJ, Sharma GV, Khuri SF, et al. Fascicular conduction disturbances after coronary artery bypass surgery: a review with a meta-analysis of their long-term significance. J Card Surg. 2006; 21 : 428-434. 
[15] Ferrari AD, Süssenbach CP, Guaragna JC, et al. Atrioventricular block in the postoperative period of heart valve surgery: incidence, risk factors and hospital evolution. Rev Bras Cir Cardiovasc. $2011 ; 26: 364-372$.

[16] Pires LA, Wagshal AB, Lancey R, et al. Arrhythmias and conduction disturbances after coronary artery bypass graft surgery: epidemiology, management, and prognosis. Am Heart J. 1995; 129: 799-808.

[17] Gordon RS, Ivanov J, Cohen G, et al. Permanent cardiac pacing after a cardiac operation: predicting the use of permanent pacemakers. Ann Thorac Surg. 1998; 66: 1698-1704.

[18] Piantá RM, Ferrari AD, Heck AA, et al. Atrioventricular block in coronary artery bypass surgery: perioperative predictors and impact on mortality. Rev Bras Cir Cardiovasc. 2015; 30: 164-172.

[19] Caspi Y, Safadi T, Ammar R, et al. The significance of bundle branch block in the immediate postoperative electrocardiograms of patients undergoing coronary artery bypass. J Thorac Cardiovasc Surg. 1987; 93: 442-446.

[20] Mosseri M, Meir G, Lotan C, et al. Coronary pathology predicts conduction disturbances after coronary artery bypass grafting. Ann Thorac Surg. 1991; 51: 248-252.

[21] Hippeläinen M, Mustonen P, Manninen H, et al. Predictors of conduction disturbances after coronary bypass grafting. Ann Thorac Surg. 1994; 57: 1284-1288.

[22] Kim MH, Deeb GM, Eagle KA, et al. Complete atrioventricular block after valvular heart surgery and the timing of pacemaker implantation. Am J Cardiol. 2001; 87: 649-651.

[23] Goldman BS, Hill TJ, Weisel RD, et al. Permanent cardiac pacing after open-heart surgery: acquired heart disease. Pacing Clin Electrophysiol. 1984; 7: 367-371.

[24] Koplan BA, Stevenson WG, Epstein LM, et al. Development and validation of a simple risk score to predict the need for permanent pacing after cardiac valve surgery. J Am Coll Cardiol. 2003; 41: 795-801.

[25] Onalan O, Crystal A, Lashevsky I, et al. Determinants of pacemaker dependency after coronary and/or mitral or aortic valve surgery with long-term follow-up. Am J Cardiol. 2008; 101: 203-208.

[26] Matthews IG, Fazal IA, Bates MG, et al. In patients undergoing aortic valve replacement, what factors predict the requirement for permanent pacemaker implantation? Interact Cardiovasc Thorac Surg. $2011 ; 12$ : 475-479.

[27] Romano MA, Koeckert M, Mumtaz MA, et al. Permanent pacemaker implantation after rapid deployment aortic valve replacement. Ann Thorac Surg. 2018; 106: 685-690.

[28] Steinberg BA, Harrison JK, Frazier-Mills C, et al. Cardiac conduction system disease after transcatheter aortic valve replacement. Am Heart J. 2012; 164: 664-671.

[29] Ribeiro V, Mota Garcia R, Frutuoso C, et al. Permanent pacemaker implantation after aortic valve replacement: long-term dependency or rhythm recovery? Rev Port Cardiol. 2015; 34 529-533.

[30] Habicht JM, Scherr P, Zerkowski HR, et al. Late conduction defects following aortic valve replacement. J Heart Valve Dis. 2000; 9: 629-632.

[31] Rene AG, Sastry A, Horowitz JM, et al. Recovery of atrioventricular conduction after pacemaker placement following cardiac valvular surgery. J Cardiovasc Electrophysiol. 2013; 24: 13831387.

[32] Chung MK. Cardiac surgery: postoperative arrhythmias. Crit Care Med. 2000; 28: N136-N144.
[33] Merin O, Ilan M, Oren A, et al. Permanent pacemaker implanta tion following cardiac surgery: indications and long-term followup. Pacing Clin Electrophysiol. 2009; 32: 7-12.

[34] Ngaage DL, Schaff HV, Mullany CJ, et al. Does preoperative atrial fibrillation influence early and late outcomes of coronary artery bypass grafting? J Thorac Cardiovasc Surg. 2007; 133: 182-189.

[35] Yesil M, Bayata S, Arikan E, et al. Should we revascularize before implanting a pacemaker? Clin Cardiol. 2008; 31: 498-501.

[36] Dawkins S, Hobson AR, Kalra PR, et al. Permanent pacemaker implantation after isolated aortic valve replacement: incidence, indications, and predictors. Ann Thorac Surg. 2008; 85: 108112.

[37] Greason KL, Lahr BD, Stulak JM, et al. Long-term mortality effect of early pacemaker implantation after surgical aortic valve replacement. Ann Thorac Surg. 2017; 104: 1259-1264.

[38] Schurr UP, Berli J, Berdajs D, et al. Incidence and risk factors for pacemaker implantation following aortic valve replacement. Interact Cardiovasc Thorac Surg. 2010; 11: 556-560.

[39] Berdajs D, Schurr UP, Wagner A, et al. Incidence and pathophysiology of atrioventricular block following mitral valve replacement and ring annuloplasty. Eur J Cardiothorac Surg. 2008; 34: 55-61.

[40] Goldstein D, Moskowitz AJ, Gelijns AC, et al. Two-year outcomes of surgical treatment of severe ischemic mitral regurgitation. N Engl J Med. 2016; 374: 344-353.

[41] Chikwe J, Itagaki S, Anyanwu A, et al. Impact of concomitant tricuspid annuloplasty on tricuspid regurgitation, right ventricular function, and pulmonary artery hypertension after repair of mitral valve prolapse. J Am Coll Cardiol. 2015; 65: 1931-1938.

[42] Jokinen JJ, Turpeinen AK, Pitkänen O, et al. Pacemaker therapy after tricuspid valve operations: implications on mortality, morbidity, and quality of life. Ann Thorac Surg. 2009; 87: 18061814 .

[43] McCarthy PM, Bhudia SK, Rajeswaran J, et al. Tricuspid valve repair: durability and risk factors for failure. J Thorac Cardiovasc Surg. 2004; 127: 674-685.

[44] Kusumoto FM, Schoenfeld MH, Wilkoff BL, et al. 2017 HRS expert consensus statement on cardiovascular implantable electronic device lead management and extraction. Heart Rhythm 2017; 14: e503-e551.

[45] Patel AM, Verma D, Jiang SF, et al. Permanent pacemaker implantation early after cardiac surgery: a descriptive study of pacemaker utility after one year of follow-up. J Card Surg. 2016; 31: 132-138.

[46] Glikson M, Dearani JA, Hyberger LK, et al. Indications, effectiveness, and long-term dependency in permanent pacing after cardiac surgery. Am J Cardiol. 1997; 80: 1309-1313.

[47] Wiggins NB, Chong DT, Houghtaling PL, et al. Incidence, indications, risk factors, and survival of patients undergoing cardiac implantable electronic device implantation after open heart surgery. Europace 2017; 19: 1335-1342.

[48] Raza SS, Li JM, John R, et al. Long-term mortality and pacing outcomes of patients with permanent pacemaker implantation after cardiac surgery. Pacing Clin Electrophysiol. 2011; 34: 331338.

(Tóth Roland dr., Zalaegerszeg, Zrínyi M. út 1., 8900 e-mail: roland.toth.sopron@gmail.com)

A cikk a Creative Commons Attribution 4.0 International License (https://creativecommons.org/licenses/by/4.0/) feltételei szerint publikált Open Access közlemény, melynek szellemében a cikk bármilyen médiumban szabadon felhasználható, megosztható és újraközölhetö, feltéve, hogy az eredeti szerző és a közlés helye, illetve a CC License linkje és az esetlegesen végrehajtott módositások feltüntetésre kerülnek. (SID_1) 